TARA SCHOELLER - BURKE

\title{
THE WRONGFUL IMPRISONMENT OF THE GUILDFORD FOUR: WHO BEARS \\ THE BLAME?
}

Submitted for the LLB (Honours) Degree

Faculty of Law

Victoria University of Wellington

2013 
Contents Page:

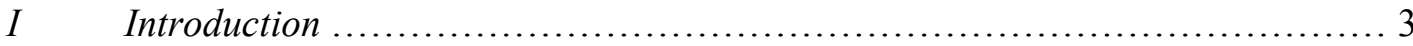

II Historical Context ......................................................... 3

A The Bombings ......................................................... 3

B 'The Guildford Four' ...................................................... 4

III The Legislature .......................................................... 6

A The Prevention of Terrorism (Temporary Provisions) Act 1974 ................. 6

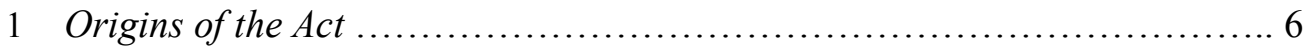

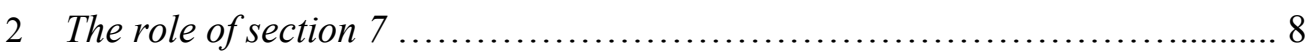

IV The Executive ............................................................ 9

A The Police ................................................................. 9

1 Bullying interrogations ............................................. 10

2 Falsified statements .................................................... 12

3 Concealed alibi evidence .............................................. 12

4 Explanations: Bad apples or systems failure? ........................... 13

B The Role of Government: A Political Injustice? ................................. 14

$V \quad$ The Judiciary ......................................................... 15

A The Trial ................................................................. 15

1 The Prosecution ....................................................... 15

2 The Defence ................................................................. 15

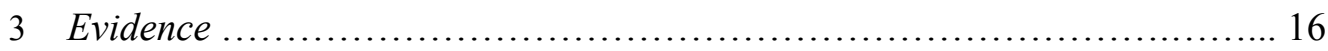

4 The Judge .......................................................... 17

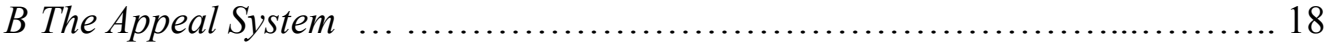

1 The 1977 Appeal ..................................................... 18

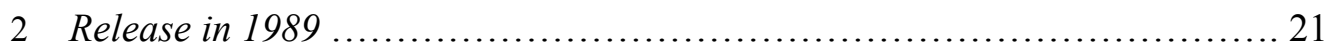

VI The Media and Public Perceptions ............................................. 23

VII Conclusions .................................................................... 23 


\section{Abstract}

This paper discusses the wrongful imprisonment of the Guildford Four, and the reasons why this miscarriage of justice occurred. Contrary to popular opinion that the injustice arose due to police malpractice, this paper will conclude that the blame lies primarily with the judiciary for failing to reverse the 1975 decision even in the face of what seemed to be insurmountable contradictory evidence. This paper analyses the role each branch of government played, as well as discussing the role of public perceptions and societal fears of the time.

\section{Keywords}

Guildford Four, Miscarriage of Justice, Counterterrorism legislation

\section{Introduction}

The role of the respective branches of government is paramount in assessing the reasons for this widely deliberated miscarriage of justice case. The legislature, through the implementation of the Terrorism Prevention Act (Temporary Measures) 1974, conferred onto police wide powers of arrest and detention, particularly through extending the period of time officers could lawfully detain accused persons without charge. This enabled police malpractice to thrive in an already tense political context, in which there was vast pressure on officers to obtain results. While this miscarriage of justice was due to a comprehensive failure on the part of the justice system as a whole, the role of the judiciary in both securing and sustaining the wrongful convictions was arguably the most prevalent. The appeals procedure in the case of the Guildford Four failed to expose or accept the errors of judgement made in the initial trial, which is representative of the reluctance on behalf of the British judiciary to have to admit faults within itself. Upholding the reputation of the judiciary was evidently considered to be of higher importance than granting innocent individuals their freedom. A key lesson from the Guildford experience is the importance of protecting the liberties of the individual, especially when times are alive with fear and prejudice.

II Historical Context

A The Bombings

On 5 October 1974 two bombs were planted in public houses in Guildford, located 30 miles southwest of London; the Horse and Groom and the Seven Stars. Guildford was 
the opening attack in a new IRA offensive on the mainland, as part of a redoubled effort to drive the British out of Northern Ireland. Four soldiers and one civilian were killed, whilst a further 57 were injured. ${ }^{1}$ The atmosphere both locally and nationally in the wake of the Guildford attack was tense. There were increased clashes between the town's small Irish community and the locals, pub managers began to ban soldiers from frequenting their bars (driven by fears of a repeat bombing) and wire netting was erected inside bar windows to break the flight of any bomb that may be thrown in. ${ }^{2}$ Conservative Politicians were quick to call for the restoration of capital punishment, among them a criminal barrister who would proceed to prosecute the Guildford Four, Sir Micheal Havers. ${ }^{3}$ The Surrey Bomb squad was formed in response to national pressure to find those responsible, and one hundred and fifty detectives were drafted in from across the region. ${ }^{4}$ The main lines of enquiry focussed on both available intelligence information on who was currently operational and capable of organizing an expert time bombing within the IRA, and locating the 380 customers of the pubs in order to trace, interview and eliminate possible suspects. ${ }^{5}$

$B$

'The Guildford Four'

Paul Hill, Gerard Conlon and Patrick Armstrong each came to England individually to find employment and escape the turbulent times in West Belfast. Although senior provisional IRA sources have always denied that Hill was a member, Hill himself conceded in 1985 that he was involved to a limited extent. ${ }^{6}$ It was due to Hill's friendship with Martin Skillen that Hill got involved in the single event that linked him to the Provisional IRA and brought him to the attention of the security forces. On 20 July 1974 Brian Shaw was found dead, executed by the IRA as a suspected army spy. ${ }^{7}$ While Skillen carried out the shooting, Hill was held to be an accomplice to Shaw's murder due to his connections to Skillen. Hill left for England in August to avoid the security forces and being questioned by the IRA for a separate incident involving Hills

\footnotetext{
${ }^{1}$ Robert Kee Trial and Error: The True Events Surrounding the Convictions and Trials of the Guildford Four and the Maguire Seven (Penguin Books, London 1989) at 11.

${ }^{2}$ Grant McKee and Ros Franey Time Bomb: Irish Bombers, English Justice and the Guildford Four ( Bloomsbury, London, 1988) at 51.

${ }^{3}$ McKee and Franey, above n 2, at 32; and (28 November 1974) 882 GBPD HC 644.

${ }^{4}$ McKee and Franey, above n 2, at 47.

${ }^{5}$ McKee and Franey, above n 2, at 48.

${ }^{6}$ Hill: "Sure I was involved, I'm not denying that. We were in a transition period where people were going from battalion structure to the cell structure. There were only four of us left in D company." McKee and Franey, above n 2, at 69.

${ }^{7}$ McKee and Franey, above n 2, at 71.
} 
apparent misappropriation of a weapon (a serious offence in the IRA lexicon, worthy of either a 'knee capping' or death). ${ }^{8}$

Hill's childhood friend Conlon never showed any interest in becoming an IRA recruit, nor was he sought after. The IRA had no use or desire for a petty criminal who liked "money, drink, gambling and girls". ${ }^{9}$ Conlon financed his costly tastes through minor thefts, and spent his time in London floating in and out of public hostels which provided refuge for Irish Catholics in England. Patrick Armstrong went to school with Conlon and Hill; however the four year age gap meant they had little to do with each other until a chance meeting reunited them in London. Conlon described Armstrong as a "timid, mild man" who had no criminal convictions. ${ }^{10}$ He helped organize events for charity and worked with elderly people as a member of the Catholic Young Men's Association. ${ }^{11}$ Armstrong's girlfriend was 17 year old Carole Richardson. The "very young and very English" Richardson followed a similar lifestyle to Hill, Conlon and Armstrong; existing of sporadic employment, squat living, petty crime and drug abuse. $^{12}$

All four were fairly rootless individuals who had often been at the margin of society and the law. There is no indication however that any of them were financed by the IRA. The IRA had an extensive catalogue of trained members to avoid relying on such amateurs. Despite their status as unlikely suspects they were arrested within two months of the bombings. Hill was arrested on 28 November 1974 under the Prevention of Terrorism (Temporary Provisions) Act 1974 (the first to be arrested under the Act) and made a written confession within 24 hours implicating Conlon. ${ }^{13}$ There is ambiguity surrounding the reasons for Hill's arrest but the contemporary version of the Surrey police is that the lead came from an anonymous, unverifiable tip by a military intelligence officer, who considered Hill to be suspect since the Shaw affair. ${ }^{14}$ Conlon was arrested in Belfast two days later, also confessing after three days of rigorous

\footnotetext{
${ }^{8}$ McKee and Franey, above n 2, at 75.

${ }^{9}$ Gerry Conlon Proved Innocent: The story of Gerry Conlon of the Guildford Four (Penguin Group, London, 1990) at 28.

${ }^{10}$ Conlon, above n 9 , at 53.

${ }^{11}$ McKee and Franey, above n 2, at 118.

${ }^{12}$ Conlon, above n 9, at 54.

${ }^{13}$ Paul Hill and Ronan Bennett Stolen Years: Before and After Guildford (Transworld Publishers Ltd, London, 1990) at 61.

${ }^{14}$ McKee and Franey, above n 2, at 88; and Clive Borrell "IRA informer got $£ 350$ for vital clue that led to bombers" The Times (England, 23 October 1975) at 5.
} 
interrogations, implicating Armstrong and Richardson in the process. On 3 December 1974, Armstrong and Richardson were arrested in an extremely drug induced state and within 48 hours succumbed to police pressure and made self-incriminating admissions. ${ }^{15}$ All four had been denied access to a solicitor for several days and retracted their confessions shortly after interrogations.

\section{The Legislature}

A The Prevention of Terrorism (Temporary Provisions) Act 1974

\section{$1 \quad$ Origins of the Act}

At the general election on 10 November 1974 Harold Wilson's Labour government returned, and Roy Jenkins was reappointed Home Secretary. ${ }^{16}$ Rumours swept through the Parliamentary lobby system that the Home Secretary was examining a range of legislative measures to combat the IRA. ${ }^{17}$ Explosions in Birmingham on the 21 November 1974, which killed 21 people and injured 150 more, made public and political clamour for new legislation against the IRA irresistible. Parliament's reaction to the bombings was influenced by two competing considerations - On the one hand there was the view that much could already be achieved to combat terrorism via the fullest application of the criminal law. ${ }^{18}$ On the other hand, the strong desire to respond to what was perceived as "the greatest threat to the country since the end of the Second World War" brought about calls for dictatorial legislation with far reaching powers. ${ }^{19}$ Debates in the House of Commons on provisions of the Act highlighted the fact that Birmingham and Guildford were no isolated events, but part of a larger climate of violence that had to be brought to an end. ${ }^{20}$ It was by means of the Prevention of Terrorism Bill that the terrorist threat was to be alleviated, where national security considerations took priority over competing civil liberty concerns.

\footnotetext{
${ }^{15}$ McKee and Franey, above n 2, at 88.

${ }^{16}$ McKee and Franey, above n 2, at 50.

${ }^{17}$ McKee and Franey, above n 2, at 50.

18 (28 November 1974) 882 GBPD HC 656.

${ }^{19}$ Clive Walker The Prevention of Terrorism in British Law (Manchester University Press, Manchester, 1986) at 22; and (28 November 1974) 882 GBPD HC 643 and 657.

${ }^{20}$ (28 November 1974) 882 GBPD HC 650.
} 
On 27 November 1974 Jenkins introduced the Prevention of Terrorism (Temporary Provisions) Bill containing "draconian measures unprecedented in peacetime."21 The Bill was passed two days later with no dissent. The Act is often portrayed as a Bill hastily drawn up in response to a single event, however this is misleading. There had been a number of terrorist attacks on the mainland since 1973 and Parliament had close precedents for counterterrorism legislation at its disposal. ${ }^{22}$ The Act, which built on the existing antipathy towards the Irish in contemporary England, was limited to Irish terrorism since there was no time to design a more comprehensive statute. ${ }^{23}$ This was a point of contention in the House of Commons; there were fears that limiting the application of the Act to terrorist acts connected to Northern Ireland would allow it to be used as a weapon to maintain an unjustified status quo. ${ }^{24}$ According to Hillyard in an extensive study published in 1993, the Act constructed a 'suspect community' against a background of Irish racism. ${ }^{25}$ There was no resolute effort to ensure the Act respected civil liberties and existing legal traditions thus it did not contain any limiting principles. The nature of the Act correctly illustrates Lord Scarman's warning in Liversidge $v$ Anderson [1942]: ${ }^{26}$

When times are normal and fear is not stalking the land, English law sturdily protects the freedom of the individual and respects human personality. But when times are abnormally alive with fear and prejudice, the common law is at a disadvantage: it cannot resist the will, however frightened and prejudiced it may be, of Parliament.

The Act created a dual track justice system within Britain whereby those suspected of political violence connected with Northern Ireland and those suspected of ordinary crime were subject to very different investigative and custodial powers. Ordinary criminals continued to be dealt with under the criminal law while those suspected of political violence were dealt with under a system that provided far fewer safeguards in

\footnotetext{
${ }^{21}$ Keith Weston 'Counter Terrorism Policing and the Rule of Law: The Best of Friends' in Nigel D. White (ed) Counter Terrorism: International Law and Practise (Oxford University Press, Oxford 2012) at 345.

${ }^{22}$ The Northern Ireland (Emergency Provisions Act) 1973, Prevention of Violence (Temporary Provisions) 1939, Immigration Act 1971.

23 (28 November 1974) 882 GBPD HC 657.

24 (28 November 1974) 882 GBPD HC 657.

${ }^{25}$ Brenda J. Lutz and James M. Lutz "The trial of the Guildford Four: Government Error or Government Persecution?" (2010) 14 TPV 113; and Paddy Hillyard Suspect Community: Peoples Experience of the Prevention of Terrorism Acts in Britain (Pluto Press, England, 1993)

${ }^{26}$ Walker, above n 19, at 24.
} 
respect of civil liberties. ${ }^{27}$ Key changes implemented by the Act were the proscription of organisations listed under Schedule 1 (The IRA had previously only been banned in Northern Ireland), the right to make exclusion orders against any person concerned in the commission, preparation or instigation of acts of terrorism and the extension of police powers of arrest and detention under section $7 .^{28}$ For the purposes of assessing the role the Act played in imprisoning the Guildford Four, the powers conferred under section 7 are fundamental.

\section{The role of section 7}

Section 7(2) extended the period of detention without charge from 48 hours to seven days, provided that the extension has been sanctioned by the Secretary of State. ${ }^{29}$ During this protracted detention the Act provided no requirement for the police to allow suspect's access to a solicitor. It also provided no guidance as to the types of cases which would sufficiently justify the extension of the detention period, and kept it as wide as "any particular case." ${ }^{30}$ As none of the Four were charged within the two day period, all the charges could be said to be an immediate product of the new powers. Hill, Conlon, Armstrong and Richardson were all subject to lengthy interrogations, while consistently being reminded of the further five days of confinement and interrogations that they would endure if they failed to confess. ${ }^{31}$ If the seven day detention period had not been introduced or widely enforced, and/or legal access had been permitted, the more likely scenario is that the four would not have confessed and the sole evidence used by the prosecution to connect them to the bombings would not have existed.

On implementation of the Bill Jenkins told the House of Commons that the measures made permissible under section 7 would result in the infringement of civil liberties, but that these would be used as "selectively" as possible. ${ }^{32}$ He nevertheless conceded that they would still "inconvenience" some people who may not deserve it. ${ }^{33}$ The powers conferred were not used selectively: Out of the first 594 applications for this extension

\footnotetext{
${ }^{27}$ Paddy Hillyard "The Politics of Criminal Injustice: The Irish Dimension” in Mike McConville (ed) Criminal Justice in Crisis (Edward Elgar Publishing, Surrey, 1994) 69 at 72.

${ }^{28}$ Prevention of Terrorism (Temporary Provisions) Act 1974

${ }^{29}$ Prevention of Terrorism (Temporary Provisions) Act 1974, s7(2)

${ }^{30}$ Walker, above n 19 , at 29.

${ }^{31}$ Conlon, above $\mathrm{n} 9$, at 78

32 (28 November 1974) 882 UKPD HC 634.

${ }^{33}$ McKee and Franey, above n 2, at 85
} 
the Home Secretary refused only two. ${ }^{34}$ Contrary to Jenkins's forecasts, it was a power used consistently and only refused in exceptional cases. It is evident in the case of the Guildford Four that the detention period did more than merely "inconvenience" innocent people, but played a key role in incarcerating them for the majority of their youth.

The detention period permitted via section 7 was later criticized by the European Court of Human Rights (ECHR) in the case of Brogan and others. ${ }^{35}$ Four persons (separate to the Guildford Four) had been subjected to prolonged detention without arrest, discharge or being promptly brought before a judge due to the powers conferred under section 7 . The ECHR held all four cases had violated several paragraphs of Article 5 of the Convention, the right to liberty and security. ${ }^{36}$ The British government responded by announcing its intent to derogate from the Convention and maintain the extended detention period due to the context of the terrorist campaign and the overriding need to bring terrorists to justice. ${ }^{37}$ This announcement was made in 1988, less than a year before the Guildford Four were to be released and have their convictions overturned as unsafe. Legislative policy in 1974 favoured state security over the security and rights of the individual, and it is doubtful whether the position has in fact changed in the UK today. By section 12(1) the 1974 Act was due to expire on the 28 May 1975, however due to continued conflict the Act was renewed on a regular basis. ${ }^{38}$ In March 1989 legislation was introduced to replace the temporary measures and made the powers conferred a permanent feature of the statute books. ${ }^{39}$

The role of the legislature in the context of the Guildford Four was ultimately to act as an enabler. It implemented repressive legislation that was exclusively applicable to the Northern Ireland conflict, which in turn enabled the executive branch to exploit and misuse the powers conferred upon it.

IV The Executive

A The Police

\footnotetext{
${ }^{34}$ McKee and Franey, above n 2, at 143.

${ }^{35}$ Brogan and others $v$ the United Kingdom (11209/84) Plenary Court, ECHR 29 November 1988.

${ }^{36}$ Antonio Tanca 'Human Rights, Terrorism and Police Custody: The Brogan Case' (1990) 1 EJIL 269.

${ }^{37}$ Tanca, above $\mathrm{n} 36$, at 277.

${ }^{38}$ Walker, above n 19 , at 24.

${ }^{39}$ The Prevention of Terrorism (Temporary Provisions) Act 1989.
} 
The Guildford Four act as a perfect illustration of the dangers of granting the police force with broad powers of arrest and detention in an already fraught political context. The pressure on police to get results is understandably of a very different degree following acts of political violence, in contrast to most instances of ordinary crime. The PTA facilitated police corruption to thrive at a time when the police force was systematically straining under the political and public pressure to find those responsible.

In the immediate aftermath of the bombings the Surrey police took 4000 statements and 600 photographs, interviewed 6000 people and initiated 2000 further factual inquiries, at a cost of $\$ 1,500,000$ for 20,000 hours of overtime. ${ }^{40}$ Police had virtually exhausted their efforts to little avail, while the list of politically motivated bombings continued to grow. Once Hill, Conlon, Armstrong and Richardson were detained, an inept police investigation followed, where incidents of police malpractice were frequent. The Surrey police effectively preordained a conviction for the Four, greatly facilitated by the passage of the PTA. Suspects in terrorism cases should be tried within the rule of law, protected against arbitrary arrest and detention, protected against discrimination and should not be subjected to torture or degrading treatment. ${ }^{41}$ The Surrey police failed in this respect on all counts.

\section{Bullying interrogations}

Police conduct in 1974 was governed by the Judges' Rules. The police maintained throughout the trial that their interrogations were conducted in accordance with them; however confessions or statements can only be used as evidence if they are given voluntarily. ${ }^{42}$ The Judges' Rules accept police interrogation in custody so long as it does not go so far as to force or induce a confession against the suspect's will "by fear of prejudice or hope of advantage, exercised or held out by a person in authority, or by oppression". 43

The methods of interrogation used on the four overstepped the proper bounds of police conduct. The four suffered from police interrogation techniques designed to break down suspects - including sleep deprivation by constant exposure to light and noise,

\footnotetext{
${ }^{40}$ McKee and Franey, above n 2, at 52.

41 Irwin Cotler "Towards a Counter-Terrorism Law and Policy" (1998) 10 TPV 1 at 4.

${ }^{42}$ Doreen McBarnet “The Royal Commission and the Judges' Rules” (1981) 8 BJLS 109 at 109.

${ }^{43}$ McBarnet, above n 42, at 109.
} 
food deprivation, severe verbal abuse, strip searches, being held in solitary confinement, long enforced periods of standing and physical abuse and beatings. ${ }^{44}$ Each of the four consistently maintained the confessions were obtained by violence and threats. Hill detailed: ${ }^{45}$

We insisted that we had made the admissions only after being brutalized, ill-treated and threatened, and that they consisted of a mixture of innocent background information, pure invention and details of the Guildford bombings supplied by the police themselves.

Conlon also alleged that Walter Simmons, a Surrey police officer investigating the bombings, made threats to arrange a 'sectarian murder' of his mother and sister in Belfast. ${ }^{46}$ Richardson got so distressed during her interrogation that she had to be seen by a police surgeon, and has recollection difficulties due to being given 20 capsules of sedative medication on the day of her arrest. ${ }^{47}$ As Richardson was participating in heavy drug use prior to being arrested she was also suffering from barbiturate withdrawal at the time of her confession. Through interrogating her in such a state, police officers improperly took advantage of the fact that she was drug affected when taken into custody. ${ }^{48}$

The police forces' claims of innocence were stated in the context of a decade where police were given no formal training on questioning suspects and the Judges' rules that were designed to secure fair procedures did not possess the force of the law, and were thus frequently ignored. ${ }^{49}$ Furthermore, instances of maltreatment at the hands of the police were not limited to the Guildford Four and similar complaints were made by the Birmingham six. ${ }^{50}$ The police officers assertions were further undermined when evidence came to light in the 1989 Appeal of the Guildford Four that trial police officers had 'seriously misled the Court' on matters regarding the timing and nature of the interrogations. ${ }^{51}$ If they lied about these matters, they are likely to have lied about

\footnotetext{
${ }^{44}$ Conlon, above n 9; and Hill and Bennett, above n 13; and Brenda J. Lutz and James M. Lutz "The trial of the Guildford Four: Government Error or Government Persecution?" (2010) 14 TPV 113 at 117.

${ }^{45}$ Hill and Bennett, above n 13, at 61 .

${ }^{46}$ Conlon, above $\mathrm{n} 9$, at 80 .

${ }^{47}$ Gisli Gudjonsson The Psychology of Interrogations, Confessions and Testimony (John Wiley \& Sons, Sussex, 1992) at 266.

${ }^{48}$ Mckee and Franey, above n 2, at 477.

${ }^{49}$ McBarnet, above $\mathrm{n}$ 42, at 110 .

${ }^{50}$ Clive Borrell "Police investigate injuries to bomb defendants" The Times (UK, 20 December 1974).

${ }^{51}$ Hill and Bennett, above n 13, at 62.
} 
the conduct administered during these interrogations. It is difficult to reconcile Hill, Conlon, Armstrong and Richardson's accounts of their interrogation experiences with the police force's claims.

\section{Falsified statements}

When it came to writing the statements and providing details of the Guildford bombings the Surrey police force played an instrumental role. The confession statements contained intricate details in regards to the bomb making, the geography of Guildford and the layout of the pub, all information which had been known to the police prior to taking the four into custody. On matters which the police knew nothing, for example who drove the car to Guildford or what the bombs looked like, the confessions were in total conflict. ${ }^{52}$ The inconsistencies in the statements lie in the areas in which the four intentionally made up details to satisfy the police and bring the interrogations to an end. The remaining matters were suggested to the detainees by the police while some of the statements were wholly dictated to them. Each of the four have separately stated they initially confessed as a way of escaping an intolerable situation with the view that they could retract their statements while in the presence of a lawyer or in the safety of a court room.

\section{Concealed alibi evidence}

The alibi evidence produced by the defendants was mixed. Conlon's alibi was that he was in a hostel at Quex Road, London on the $5^{\text {th }}$ of October. ${ }^{53}$ It was later discovered that the police were in possession of one statement by Charles Edward Burke, a Greengrocer who shared a room with Hill and Conlon at the hostel, which amounted to verification of his alibi. ${ }^{54}$ Armstrong had an alibi that he was in a squat at a time when people were being arrested, for which witnesses were available but no evidence was provided by the police to confirm this had taken place. ${ }^{55}$ Richardson's alibi evidence was by far the most compelling, as she was at a concert in South West London almost 40 miles from Guildford where she had a photograph posing with the band. ${ }^{56}$ The police maintained that Richardson could have travelled the distance and planted the

\footnotetext{
${ }^{52}$ Grant McKee "The Guildford Four" The Listener (UK, 26 June 1986)

${ }^{53}$ Gudjonsson, above $\mathrm{n} 47$, at 262.

${ }^{54}$ Jack O'Sullivan “The Guildford Four: Alibi evidence kept from defence for 14 years” The Independent (UK, 19 October 1989)

${ }^{55}$ Gudjonsson, above n 47, at 262.

${ }^{56}$ Gudjonsson, above n 47, at 266.
} 
bomb at Guildford before returning to South London 50 minutes later. A police driver who ignored the speed limit claimed to have made the journey in 45 minutes. ${ }^{57}$ The police were patently willing to use whatever measures necessary to obtain convictions of the four.

\section{Explanations: Bad apples or systems failure?}

The unremitting way in which the police continued to prosecute the four despite the overwhelming evidence to the contrary suggests there was more at play than simply a blind predetermined judgement of guilt. Two broad theories have been explored by scholars as a means of explaining illegal police conduct in miscarriage of justice cases. ${ }^{58}$ The "bad apple theory" focusses on the individual officers deviant actions and is shorthand for an individualistic model of police deviance. ${ }^{59}$ Under this explanation, it follows that by the time the Surrey police force had Hill, Conlon, Armstrong and Richardson in custody they fixed on the suspects and worked up a belief of guilt. Either they overstepped the boundaries of police conduct due to these assumptions, or they were aware of their innocence but continued regardless, due to the ease with which these four outcasts could be offered up as scapegoats. The theory of police malpractice to account for what happened lays the blame of the miscarriage of justice on a few deviant and bent police officers. ${ }^{60}$ However there are obvious issues with this theory, succinctly identified by Punch: ${ }^{61}$

The 'rotten apple theory won`t work any longer. Corrupt police officers are not natural-born criminals, nor morally wicked men [sic], constitutionally different from their honest colleagues. The task of corruption control is to examine the barrel, not just the apples - the Organization, not just the individuals in it - because corrupt police are made, not born.

It is difficult to conceive that many of those involved did not believe that some or all were innocent given the weight of the contradictory evidence which they had to go to such pains to conceal, alter and manipulate. The competing explanation argues that the

\footnotetext{
${ }^{57}$ Gudjonsson, above $\mathrm{n}$ 47, at 262.

${ }^{58}$ Julia Hall To Serve without Favour: Policing, Human Rights and Accountability in Northern Ireland (Human Rights Watch, Helsinki, 1997) at 141 and; Peter Gottschalk Knowledge Management in Police Oversight (Brown Walker Press, Florida, 2009) at 146; and Hillyard, above n 27, at 76.

${ }^{59}$ Gottschalk, above n 58, at 145 .

${ }^{60}$ Hillyard, above $\mathrm{n} 27$, at 76.

${ }^{61}$ Gottschalk, above n 58, at 146.
} 
majority of those involved in the arrests knew they were innocent but because of extraneous political circumstances of the time they were encouraged to secure convictions. This has been termed the "rotten orchard theory", and is the favoured explanation by many within the Irish community. ${ }^{62}$ This theory views the Guildford Four as convenient scapegoats, who as individuals on the periphery of society and being Irish Catholics, were consequently vulnerable. The overwhelming contradictory evidence gives credence to this explanation.

$B$

The Role of Government: A Political Injustice?

The government has chosen to justify the miscarriage of justice in terms of the bad apple theory.' This is evident by the prosecution of only three of the many officers involved in the Guildford Four case, as it shifts the blame on a small portion of the police force rather than the flaws of the police force or the justice system as a whole. Was this an example of a political injustice rather than a criminal injustice? While the trial of the Guildford Four did have political implications, this was not a partisan trial in which the conviction was virtually assured to serve the purposes of the government. ${ }^{63}$

The government did nevertheless play a key role in maintaining the convictions, and ensuring the Guildford Four remained behind bars; it was unwilling to reopen the case or admit errors had been made until forced to do so due to public indignation. The need to reassure the public of the effectiveness of the police force and the courts, limited the ability of the government either to see miscarriages had occurred or to publicly acknowledge them. Margaret Thatcher, who led the conservative party until 1990, was notorious for having a jaundiced view of Irish affairs and an uncompromising approach to the IRA. This was epitomised in her approach to the hunger strikes in which Thatcher allowed notable political figures to die in prison rather than concede to the request of being granted political prisoner status. ${ }^{64}$ In doing so, Thatcher hugely alienated the nationalist population in Northern Ireland and England. ${ }^{65}$ Her position on Irish affairs is also evident in her lack of action or comment on the Guildford Four. In Thatcher's own memoirs which are a reflection of her eleven years in power, the Birmingham six only receive a mention in a footnote and the Guildford Four merit no

\footnotetext{
${ }^{62}$ Hillyard, above n 27, at 76 and; Maurice Punch "Rotten Orchards: "Pestilence", Police Misconduct and Systems Failure" (2003) 13 IJRP 171.

${ }_{63}^{63}$ Lutz and Lutz, above n 25, at 114.

${ }^{64}$ Peter Taylor Provos: The IRA and Sinn Fein (Bloomsbury, London, 1997) at 238.

${ }^{65}$ Taylor, Above n 64, at 243.
} 
reference at all. ${ }^{66}$ Only once public campaigns for their release took place did the government pay the issue of the Guildford Four any serious attention, as continuing publicity was more damaging then an admission of error. ${ }^{67}$

While the government were guilty of inaction whilst the Four were incarcerated, the institution which played the most fundamental role in allowing this miscarriage to occur was the Judiciary. The trial of the Guildford Four opened on 16 September 1975 at the Central Criminal Court and the key point of contention was the disputed confessionary evidence.

\section{The Judiciary \\ A The Trial \\ $1 \quad$ The Prosecution}

The Prosecution argued that Hill, Conlon and Armstrong were all members of the Provisional IRA but no evidence was produced to substantiate this claim. The crown prosecution was led by Sir Michael Havers who dismissed the 140 inconsistencies and inaccuracies between the confession statements of the four defendants as an elaborate IRA counter interrogation technique. ${ }^{68}$ A newspaper reporter from the Times reporting the case in 1975 described the state of affairs as being as follows: ${ }^{69}$

The object is to confuse interrogators by answering with half-truths; that is admitting taking certain actions, and making remarks which were in fact taken and made by other members of the gang. By adopting that ruse they can confuse witnesses, especially when it comes to identification. It also makes the jury's task difficult when they have literally dozens of false statements as in this present trial. The ruse, however, has failed with the all-male jury, which for the past six weeks has unravelled the web.

In reality the inconsistencies were due to the defendant's lack of knowledge about the bombings. The ease with which the jury, the judge and the media readily accepted the prosecutions explanations of the inconsistent statements is concerning. It is a likely

\footnotetext{
${ }^{66}$ John Newsinger "Thatcher, Northern Ireland and the 'Downing Street Years"” (1994) 2 ISR 7 at 6 and; Margaret Thatcher Downing Street Years (HarperCollins, London, 1993) at 888.

${ }^{67}$ Lutz and Lutz, above n 25, at 126 .

${ }^{68}$ Gudjonsson, above n 47, at 261.

${ }^{69}$ Clive Borrell "IRA informer got $\$ 350$ for vital clue that led to bombers" The Times (UK, 23 October 1975).
} 
consequence of allowing the anti-Irish sentiment and public and political pressure to place the blame to enter the court room.

\section{The Defence}

The defence's case relied upon challenging the admissibility and reliability of the confession statements. The available alibi witnesses were produced to show the defendants had been elsewhere at the time of the bombings, but these were made to look "shifty, confused and stupid" by Havers. ${ }^{70}$ Counsel for Armstrong and Conlon suggested that a Belfast upbringing might have conditioned them to be afraid of authority, due to the systematic practises by the security forces of subjecting suspects to ill treatment. ${ }^{71}$ The defence's case would have been strengthened if evidence supporting the four's ill treatment during the interrogations had been produced. This was available in relation to Conlon as doctors in Belfast were able to attest to Conlon suffering from a kidney condition whilst being held in Belfast for which he was refused proper treatment and medication. ${ }^{72}$ Furthermore, if the defence had focussed its case more on challenging the prosecutions assertions that the Four were funded by the Provisional IRA it may have convinced the jury the IRA would never have accepted the likes of Conlon, Armstrong and Hill into their higher ranks, let alone given them the responsibility of launching a violent terrorist campaign in England. As one defence solicitor put it: "It would be like asking wally to plant a bomb. No one in their right mind would want to have anybody involved who took LSD. It's nonsensical." ${ }^{\text {73 }}$

Lord Devlin and Lord Scarman in a commentary on the Guildford Four described the current state of the law in instances where defendants have confessed as involving a presumption of guilt, rather than a presumption of innocence. The accused, according to Scarman and Devlin, "go into the dock with the halters of their confessions about their necks and unless they can slip free of them they are doomed." "T4 The defence failed because the defendants were unable to convince the jury of the falsity of their confession statements. Despite the legal position, the onus was on the Four to disprove

\footnotetext{
${ }^{70}$ Conlon, above $\mathrm{n} 9$, at 131.

${ }^{71}$ McKee and Franey, above n 2, at 284.

${ }_{73}^{72}$ Conlon, above $\mathrm{n} 9$, at 134.

${ }^{73}$ Hill and Bennett, above n 13, at 102.

${ }^{74}$ Lord Devlin and Lord Scarman "Justice and the Guildford Four: Alleged IRA bombers" The Times (UK, 30 November 1988).
} 
the accusations levelled against them, rather than on the prosecution to remove the presumption of innocence. In effect, they were tried under a presumption of guilt.

\section{Evidence}

The sole pieces of evidence against the four were the questionable confession statements. Excepting some highly circumstantial evidence surrounding similarities between a pocket watch found in Armstrong's previous residence and the watch used in the bombings, there was no identification ever produced to link the four to the bombings. $^{75}$ The confession evidence should not have been admissible in court on grounds of involuntariness. In Scotland, the case would not have even made it to court without independent corroborating evidence. ${ }^{76}$ Barrie Irving, a forensic psychologist who played a crucial role in reforming the pre-trial procedures in the English system made the following comments in regards to the evidence admitted at trial: ${ }^{.7}$

My conclusion after reading Armstrong's statements was that without corroboration in a case of this kind one is on very dangerous ground. Where there are additional problems about the way in which the interrogation was handled then one is on more difficult ground still.

Under UK law there is no requirement for the corroboration of evidence, aside from in some special cases in which there was an obligation on the judge to warn the jury that there was a risk in relying solely on the specific piece of evidence. Justice Donaldson, the presiding trial judge, failed to provide any warnings based on the lack of corroborating evidence. $^{78}$

\section{The Judge}

Mr Justice Donaldson's summary of the evidence for the jury was of exceptional length and ran to 126 pages of transcript. ${ }^{79}$ Donaldson $\mathrm{J}$ emphasised the neutrality of his role and consistently reminded the jury that the verdict 'is entirely a matter for you'. ${ }^{80}$ However it is a rare jury that does not absorb the judicial message which, even if not passed explicitly may pass through implication. Donaldson's summary was layered

\footnotetext{
${ }^{75}$ Gudjonsson, above n 47, at 261.

${ }^{76}$ McKee, above n 52.

${ }^{77}$ McKee and Franey, above n 2, at 143.

${ }^{78}$ McKee and Franey, above n 2, at 281.

${ }^{79}$ McKee and Franey, above n 2, at 281.

${ }^{80}$ McKee and Franey, above n 2, at 281.
} 
with judicial messages: He did not warn the jury of the dangers involved in relying on uncorroborated evidence, particularly confession statements made prior to the defendants being able to access a solicitor. In regards to Richardson's case, he emphasised the fact that she had been the only one to complain of police brutality while in custody but used this fact to emphasise the reliability of the police officers evidence, as they had readily admitted she had made a complaint in this instance. Ultimately the case against the four stood or fell on the confessions. Donaldson $\mathrm{J}$ framed the matter for the jury as being an issue of whether the police officers or whether the four accused had lied. ${ }^{81}$ His final words in summarising Armstrong's case would not have left the defence with much optimism: "I would not have made a false confession, but he [Armstrong] may be different from me." ${ }^{\prime 82}$

Donaldson $\mathrm{J}$ evidently perceived the four as guilty of the crimes accused. Given the subtexts conveyed in the judge's summary and the tense political climate instilling fear and distrust into the general public, it is not surprising the jury reached a unanimous guilty verdict. All four members were sentenced to life imprisonment: Richardson with a recommendation that she should not serve less than 20 years on charges of conspiracy to cause explosives, Conlon not less than 30, Armstrong not less than 35, and Hill was ordered to be detained until "either age or infirmity" decrees that he should be released. ${ }^{83}$ Donaldson $\mathrm{J}$ made it explicit to the four that prison for life must mean just that, and they should not expect to be released within $12-15$ years. ${ }^{84} \mathrm{He}$ also emphasised that had the 1965 Act abolishing the death penalty not been introduced, three of the accused would have been executed. ${ }^{85}$ In his final address Donaldson $\mathrm{J}$ famously stated: "The English language is rich in words, but no single one can adequately describe your crime." 86

\section{B The Appeal System}

It is the fundamental role of appellate courts to correct errors made, and to ensure the courts maintain consistent and equitable outcomes. The appeals procedure in the case of

\footnotetext{
${ }^{81}$ McKee and Franey, above $n$ 2, at 292: "The only people that can substantiate those allegations are the police officers and Carole Richardson."

${ }^{82}$ Clive Borrell "Prison for life must mean just that, judge tells bomber" The Times (UK, 23 October 1975) and; McKee and Franey, above n 2, at 283.

${ }^{83}$ Borrell, above n 82.

${ }^{84}$ Borrell, above n 82 .

${ }^{85}$ Borrell, above n 82.

${ }^{86}$ McKee and Franey, above n 2, at 296.
} 
the Guildford Four however persistently failed to expose or accept the deep seated injustices. The benefit of hindsight served of no advantage for the Four, who unswervingly failed in their efforts to have the injustices corrected.

\section{The 1977 Appeal}

Following the 'Balcombe Street Siege' in December 1975, four IRA members who were convicted of separate crimes, claimed during interrogation that the Court had convicted the wrong people for the Guildford bombings. ${ }^{87}$ When placed on trial they refused to plead, firstly because of the IRA custom to deny the jurisdiction and secondly because the indictment did not include two charges on which they were guilty and on which innocent people had been convicted. ${ }^{88}$ These four men were Brendan Dowd, Joseph O'Connell, Edward Butler and Harry Duggan, all of whom hailed from committed Sinn Fein families with close ties to the Provisional IRA. Lord Devlin and Lord Scarman described the Four as "fanatics for whom the truth, like themselves, was a servant of the cause." 89 The fresh evidence relating to the Balcombe Street gangs' claimed sole involvement in the Guildford bombings was presented at an appeal hearing in Guildford in October 1977. Dowd, O’Connell, Butler and Duggan gave comprehensive statements of the details surrounding the Guildford bombings, which could have only been known by them through participation.

Lord Justice Roskill, sitting with Lord Justice Lawton and Mr Justice Boreham held that there had been a "cunning and skilful attempt to deceive the Court by putting forward fake evidence." $" 90$ The judges dismissed scientific evidence indicating that the Guildford bombings were virtually identical to other bombings committed by the Balcombe street gang. Although there had been no evidence to show that the IRA men had ever been in contact with the Guildford Four, they concluded it was a case of the IRA supporting the IRA. ${ }^{91}$ This was based on a letter to O'Connell which referred to "two Belfast fellows" which the judges concluded must have been Hill and Conlon. ${ }^{92}$ Lord Justice Roskill even warned Duggan prior to giving evidence at the Guildford

\footnotetext{
${ }^{87}$ Gudjonsson, above $\mathrm{n} 47$, at 263

${ }^{88}$ Lord Devlin and Lord Scarman, above $n 74$.

${ }^{89}$ Lord Devlin and Lord Scarman, above $\mathrm{n} 74$.

90 The Times "Attempt by IRA bombers to deceive court is rejected" The Times (UK, 29 October 1977)

${ }^{91}$ Ludovic Kennedy in McKee and Franey, above n 2, at foreword.

92 Aidan McQuade “Guildford Four: Justice on trial?” Fortnight (England, May 1989) at 12
} 
Appeal that he need not give evidence which incriminated himself. ${ }^{93}$ The Court again ignored the inconsistencies in the original confession evidence. Instead of sending the case back to the jury to reconsider the confession statements in light of the new evidence, the bench assessed the case themselves and refused to quash the convictions. The Court described the confessions as "the partially true intermingled with the deliberately false." 94 It concluded that even if the four men were involved in the bombings to some extent, this must have been with the assistance of the Guildford Four, and the convictions of the Guildford Four should therefore not be quashed. The judges decided that; "We are all of the clear opinion that there are no possible grounds for doubting the justice of any of these convictions." 95

The 1977 Appeal decision has come under considerable criticism within the legal community, particularly from Lord Devlin and Lord Scarman in their 1988 report entitled; 'Justice and the Guildford Four: Alleged IRA bombers.' It is exemplary of the deep reluctance on behalf of the judiciary to have to admit major miscarriages of justice. The UK appeal structure is historically an appeal structure that is reluctant to reopen cases. Prior to the Criminal Appeal Act of 1907 creating the Criminal Appeal Court, there was no appeal available from a ruling and the sleep of the final verdict lay undisturbed. ${ }^{96}$ The 1907 Act allowed appeals involving fresh evidence, but conferred no powers onto a Court to order a retrial. As a result, all that could be done if the evidence was credible was to quash the verdict. ${ }^{97}$ The Criminal Appeal Act of 1968 reformed the law and allowed a retrial in cases in which fresh credible evidence had come to light, which, according to Devlin and Scarman, should naturally be by jury, as this is how all indictable crime had been tried for centuries. ${ }^{98}$ If the Court has received new evidence which might destroy the verdict, that is a circumstance which alters the case and must either be set aside as unsafe or a retrial must be ordered. What the Court of Appeal essentially did in the 1977 Appeal was a retrial without the jury, reinstating a fresh guilty verdict without allowing a jury to hear the fresh evidence.

This is the aspect of the appeal that Lords Scarman and Devlin are most critical of. It was, as Devlin and Scarman put it, a case of the Appeal judges usurping the role of the

\footnotetext{
93 The Times "IRA Gunman took part in bombing" The Times (UK, 14 October 1977)

${ }^{94}$ Lord Devlin and Lord Scarman, above $\mathrm{n} 74$.

95 The Times, above $\mathrm{n} 90$.

${ }^{96}$ Lord Devlin and Lord Scarman, above $n 74$.

${ }^{97}$ Lord Devlin and Lord Scarman, above $n 74$.

${ }^{98}$ Lord Devlin and Lord Scarman, above n 74.
} 
jury. They were also hugely critical of the House of Lords decision of DPP $v$ Stafford [1974] which enabled the Court of Appeal to interpret the Act in such a way that allowed judges to hear and determine new evidence for themselves. In so doing, the House put a wider construction on the Criminal Appeal Act, vastly minimizing the role of juries in retrials. ${ }^{99}$ The Act's role in achieving fair and equitable results through retrials has been eroded due to the interpretation put on it by both the House of Lords ${ }^{100}$ and the Court of Appeal. Judges were taking on the role of the jury as triers of fresh evidence. Roskill and his peers disbelieved the witnesses, therefore held a jury would do the same. An official retrial should have been ordered and the fresh evidence of the Balcombe Street gang should have been put to the jury to decide on. Had this been so, the injustice may have been corrected in a much shorter period.

The ultimate question therefore is why Roskill and his colleagues, all educated men, allowed common sense to desert them when they had the advantage of hearing reliable testimony from the legitimate bombers? The answer is the deep reluctance on the behalf of the judiciary to have to admit to major miscarriages of justice, in particular given the political context of the time. ${ }^{101}$ There was a conviction held by several senior judges and politicians that it was for the good of the people that they believe the legal process is above error. ${ }^{102}$ However like all human institutions, the courts are fallible. Instead of attempting to perpetuate the fantasy of judicial infallibility, Roskill and his peers should have focussed on correcting judicial errors. As Cyril Connolly suggested in 1961, the real test of a country's justice "is not the blunders that are sometimes made but the zeal with which they are put right." $" 103$ The eventual release of the Guildford Four in 1989 was due to surmounting public pressure to have the case reviewed, not due to actions taken within the judicial realm. The Balcombe Street gang was never charged in relation to the Guildford Four bombings.

\section{Release in 1989}

On the $16^{\text {th }}$ January 1989 the Home Secretary announced that the case of the Guildford Four was to be referred back to the Court of Appeal. New evidence had been produced

\footnotetext{
${ }^{99}$ Lord Devlin and Lord Scarman, above n 74.

${ }^{100}$ DPP v Stafford [1974] AC 878 (HL).

${ }_{101}$ McKee and Franey, above n 2, at foreword.

${ }^{102}$ McQuade, above n 92, at 13.

${ }^{103}$ McQuade, above n 92, at 13.
} 
concerning Richardson's mental state at the time of her confession. ${ }^{104}$ Avon and Somerset police who were appointed by the Home Secretary to look at the confession evidence of the four discovered alterations made to the accused's initial statements. ${ }^{105}$ Dates had been altered or typed over, which indicated that written records were not kept at the date of the interrogations, but instead were written by the police in 1975 for the purposes of the initial trial. The confession evidence which was held by police to be contemporaneous was recorded a year after the interrogations took place. Lord Lane conceded that the police officers "had lied" at the trial of the Guildford four. ${ }^{106}$ The convictions were quashed on the second appeal on the grounds that the initial convictions were unsafe, as "if [the police] were prepared to tell this sort of lie then the whole of their evidence becomes suspect." ${ }^{107}$ The injustice remained unaddressed for twelve years before wrongs were finally righted in the 1989 Appeal. Therefore, while the Four have the Court of Appeal to thank for their eventual release, Lord Lane and his peers were merely performing the functions of their job successfully, something the 1977 appeal judges failed in doing.

Lord Lane expressed the hope that the prosecution of the three police officers who were accused of subverting the course of justice would follow speedily; however it was not until a year after the discovery of the suspect statements that the three officers were even invited to attend a formal interview in London accompanied by solicitors. ${ }^{108}$ On 22 November 1990 the Crown Prosecution Service announced that the three detectives were to be charged with conspiracy to pervert the course of justice, which, under normal circumstances, would expect a trial within six to nine months. In June 1991 lawyers for the detectives made an abuse of process application claiming that the case should be dismissed due to time lapse since 1974 and because the officers could not expect a fair trial due to the adverse publicity. ${ }^{109}$ Although the application was initially upheld, the charges were reinstated by the High Court and the trial was eventually fixed for April 1993. All three officers were swiftly acquitted; giving credence to Ronan

\footnotetext{
${ }^{104}$ Gudjonsson, above $\mathrm{n} 47$, at 263.

105 Gudjonsson, above n 47, at 264.

${ }^{106}$ Robert Rice "Judges quash Guildford bomb convictions: The reasons for reversing the contested trial decision of 1975" The Financial Times (London, 20 October 1989) .

${ }^{107}$ Ronan Bennett "Criminal Justice" (1993) 15 LRB 3.

${ }^{108}$ Bennett, above $\mathrm{n} 107$, at 5.

${ }^{109}$ Bennett, above n 107, at 7.
} 
Bennett's conviction that the case was a mere theatrical production, at the end of which British justice was to prosper. ${ }^{110}$

\section{The Media and Public Perceptions}

The miscarriage of justice happened under the noses of a consenting public and an approving media. The quality of justice was strained in the case of Irish defendants facing trials in British courts for political offences due to the public perceptions of the time, and the Irish being viewed largely as a 'suspect community' within the British justice system. ${ }^{111}$ This was also conveyed through the medium of the media. There were significant differences in the way Irish people were perceived by the police and the wider public in comparison to other ethnic groups in the 1970s. This was largely based on popular prejudices and influenced by policing history. The treatment of the Irish in the $17^{\text {th }}$ Century by Cromwell's forces was one of massacre, religious persecution, and mass dispossession of the Catholic community. This evolved in the $19^{\text {th }}$ Century to perceiving the Irish as an inferior race who were stereotypically violent, drunk and dishonest. These historically rooted prejudices resurfaced in the 1970s in the wake of the conflict and it is evident that race played a role in securing the convictions. Headlines in the popular press which applauded police efforts and failed to question the irregularities or obvious discrepancies in the case were likely to be prejudicial to subsequent court cases.

The role of an independent media and voting public is to act as a watchdog role as a guardian of the public interest. It is in the public interest to ensure civil liberties are protected. The Prevention of Terrorism Act was not legislated with such trepidations in mind, and the police officers who interrogated the four did not consider the civil liberties of the accused as a limitation on their policing powers. Aside from a select few who argued their innocence from the beginning, the public and the media failed in their role of ensuring civil liberties were not eroded or abused. Instead the public and the media fell prey to the tense political context of the time, and fanned the flames of discord by taking sides and reinforcing prejudices.

\section{Conclusions}

\footnotetext{
${ }^{110}$ Bennett, above n 107, at 6.

${ }^{111}$ Hillyard, above n 27.
} 
In the immediate aftermath of the release of the Guildford Four, increased commentary on the state of the criminal justice system was undertaken. A reporter for the Guardian succinctly stated: ${ }^{12}$

I have always felt a sense of unease about it. There was something not quite right about the defendants. They didn't seem to have the right calibre, the right stuff for these sorts of offences. They didn't have the self-contained air of the Provos. [sic] But there was never any doubt throughout the case that they were going to be convicted.

Under a legal system that allowed extended detention under the Prevention of Terrorism Act, and conviction on the basis of uncorroborated confessions alone, it is not surprising that the Guildford Four were convicted. Holistically, it is clear that each branch of government had a role to play: The legislature through the implementation of the PTA, the executive through the conduct of the police force, and the judiciary through the questionable 1977 Appeal. The Guildford experience also needs to be viewed in the larger context as a symptom of the stress that violence places on the institutions of a democratic society trying to respond to the attacks on its very existence while balancing its commitments to the rule of law. It has long been acknowledged that terrorism and free institutions do not mix very well and societies under siege frequently deal with self-preservation in ways that trample civil liberties, or in the England specific context, through the passage of the PTA. ${ }^{113}$ The role of the PTA (or, in a wider sense, the legislature) in the case of the Guildford four was to act as an 'enabler', empowering the police to depart from normal legal standards and engage in pre judgement, prejudice and stereotyping.

The police authorities either deluded themselves into believing the Guildford Fours guilt or continued regardless, which, in the light of the overwhelming evidence they had supporting the innocence of the Four, is the more likely scenario. Regardless, the blame of the miscarriage of justice does not rest solely on the corrupt characters of a select few individuals, despite this being the favoured government position. It was almost understandable (but not defensible) that the Guildford police, aware of the sense of public outrage and anger brought about by the bombings and under great pressure to find perpetrators, would sacrifice a few individuals living on the fringe of society in

\footnotetext{
${ }^{112}$ McKee and Franey, above $\mathrm{n} 2$, at 300

${ }^{113}$ Abraham H. Miller "Preserving Liberty in a Society under siege: The media and the Guildford Four" (1990) 2 TPV 305
} 
order to gain the greater societal benefit of restoring public confidence in the police force as an institution. Given the breadth of powers they were conferred under the PTA, officers may have even assumed harsher forms of police interrogation were encouraged as part of the legislative intent.

In allowing this miscarriage of justice to occur, or providing an explanation as to why it did occur, it is the British judiciary that played the most fundamental role. The capacity of the UK judicial system for finding fault within itself is evidently limited. ${ }^{114}$ The conduct of the Appeal Court judges in 1977 in explaining away the accurate accounts as to how four separate convicted IRA men planted the Guildford bombs was undoubtedly ingenious. In light of this hugely damaging evidence, a retrial was refused and convictions remained. The Guildford Four were to remain incarcerated for another twelve years before the injustice would be rectified at the second appeal. Despite the appellate judges having the benefit of hindsight, and less political and public clamour surrounding the case, they were unable to evaluate the case in a non-partisan manner. Maintaining public confidence in an unfailing judiciary was of higher importance then justice being achieved on an individual level. No reputation, either of an individual or of a national system of justice, should condone wrongful imprisonment. The slogan fiat justitia, ruat caelum, once a proud judicial mantra that 'justice be done though the heavens may fall', has manifestly been eroded in instances where the achievement of justice would cause the reliability of the British judiciary to be called into question.

${ }^{114}$ Bob Woffinden Miscarriages of Justice (Hodder and Stroughton, London 1988) at 316 
Bibliography:

Texts

Boyle, Kevin and Hadden, Tom and Hillyard, Paddy Law and State: The case of Northern Ireland (Martin Robertson and Co, London, 1975)

Conlon, Gerry Proved Innocent: The story of Gerry Conlon of the Guildford Four (Penguin Group, London, 1990)

Gottschalk, Peter Knowledge Management in Police Oversight (Brown Walker Press, Florida, 2009)

Gudjonsson, Gisli The Psychology of Interrogations, Confessions and Testimony (John Wiley \& Sons, Sussex, 1992)

Hall, Julia To Serve without Favour: Policing, Human Rights and Accountability in Northern Ireland (Human Rights Watch, Helsinki, 1997)

Hill, Paul and Bennett, Ronan Stolen Years: Before and After Guildford (Transworld Publishers Ltd, London, 1990)

Hillyard, Paddy "The Politics of Criminal Injustice: The Irish Dimension” in Mike McConville (ed) Criminal Justice in Crisis (Edward Elgar Publishing Ltd, England, 1994)

Hillyard, Paddy Suspect Community: Peoples Experience of the Prevention of Terrorism Acts in Britain (Pluto Press, England, 1993)

Kee, Robert Trial and Error: The True Events Surrounding the Convictions and Trials of the Guildford Four and the Maguire Seven (Penguin Books, London 1989)

McKee, Grant and Franey, Ros Time Bomb: Irish Bombers, English Justice and the Guildford Four ( Bloomsbury, London, 1988)

Taylor, Peter Provos: The IRA and Sinn Fein (Bloomsbury, London, 1997)

Thatcher, Margaret Downing Street Years (HarperCollins, London, 1993)

Walker, Clive The Prevention of Terrorism in British Law (Manchester University Press, Manchester, 1986) 
Weston, Keith 'Counter Terrorism Policing and the Rule of Law: The Best of Friends' in

Nigel D. White (ed) Counter Terrorism: International Law and Practise (Oxford University Press, Oxford 2012)

Woffinden, Bob Miscarriages of Justice (Hodder and Stroughton, London 1988)

\section{Journal Articles}

Bennett, Ronan "Criminal Justice” (1993) 15 LRB 1

Cotler, Irwin “Towards a Counter-Terrorism Law and Policy” (1998) 10 TPV 1

Field, Steward and Thomas, Phillip A "Justice and Efficiency? The Royal Commission on Criminal Justice" (1994) 21 JLS 1.

Lutz, Brenda J and Lutz, James M "The trial of the Guildford Four: Government Error or Government Persecution?” (2010) 14 TPV 113 at 117

McBarnet, Doreen “The Royal Commission and the Judges' Rules” (1981) 8 BJLS

Miller, Abraham H. "Preserving Liberty in a Society under siege: The media and the Guildford Four” (1990) 2 TPV 305

Newsinger, John "Thatcher, Northern Ireland and the 'Downing Street Years"” (1994) 2 ISR 7

Punch, Maurice "Rotten Orchards: "Pestilence", Police Misconduct and Systems Failure" (2003) 13 IJRP 171

Scorer, Catherine "The United Kingdom Prevention of Terrorism Acts, 1974 and 1976" (1980) 10 IJP 105.

Tanca, Antonio "Human Rights, Terrorism and Police Custody: The Brogan Case" (1990) 1 EJIL 269

\section{Legislation (UK)}

Prevention of Violence (Temporary Provisions) 1939

Immigration Act 1971

The Northern Ireland (Emergency Provisions Act) 1973 
The Prevention of Terrorism (Temporary Provisions) Act 1974

The Prevention of Terrorism (Temporary Provisions) Act 1989

\section{Parliamentary Debates}

(28 November 1974) 882 GBPD HC

\section{Newspaper Articles}

Borrell, Clive "Defendant said to have taken bomb into Guildford pub because companion threatened him with death" The Times (UK, 18 September 1975)

Borrell, Clive "Mother taught IRA recruits to make bombs" The Times (UK, 5 March 1976)

Borrell, Clive "Prison for life must mean just that, judge tells bomber" The Times (UK, 23 October 1975)

Borrell, Clive "Police investigate injuries to bomb defendants" The Times (UK, 20 December 1974)

Borrell, Clive "Police investigate injuries to bomb defendants" The Times (UK, 20 Dec 1974)

Borrell, Clive "IRA informer got $\$ 350$ for vital clue that led to bombers" The Times (UK, 23 October 1975)

Borrell, Clive "IRA Gunman took part in bombing" The Times (UK, 14 October 1977)

Borrell, Clive "Attempt by IRA bombers to deceive court is rejected" The Times (UK, 29

October 1977)

Franey, Ros “Guildford Four: Now for the Inquest” Fortnight (London, November 1989)

Lord Devlin and Lord Scarman "Justice and the Guildford Four: Alleged IRA bombers" The Times (UK, 30 November 1988)

McKee, Grant "The Guildford Four” The Listener (UK, 26 June 1986)

McQuade, Aidan “Guildford Four: Justice on trial?” Fortnight (London, May 1989)

O'Sullivan, Jack “The Guildford Four: Alibi evidence kept from defence for 14 years" The Independent (UK, 19 October 1989) 
7900 words including substantive footnotes. 